\title{
Correlations of Vegetative and Reproductive Characters with Root Traits of Upland Rice under Imposed Soil Moisture Stress
}

\author{
Nassir, A. L., Adewusi, K. M. and Olagunju, S. 0. \\ Department of Crop Production, College of Agricultural Sciences, Olabisi Onabanjo University, Yewa \\ Campus, PMB 0012, Ayetoro, Ogun State. NIGERIA.
}

\begin{abstract}
An understanding of the relationship between traits related to plant performance is advantageous in rice breeding for tolerance to drought and increase in grain yield. Correlations studies involving root, vegetative and reproductive traits were carried out with sixteen rice genotypes under differing soil moisture through a combination of three amounts of moisture and two periods of application. Data from root, vegetative and grain yield traits were used to compute phenotypic and genotypic coefficients of variation (CV), correlations and heritability. Phenotypic and genotypic CV were generally low, with the exception of root branching and grain weight per plant. Heritability estimates were also low. Among the root traits, the highest heritability value of 36.6 and 30.5 was recorded by root thickness and root branching respectively while the estimate for 100-grain weight (48.7), days to flowering (47.8) and primary branching (45.9) were moderate. Genetic advance was highest for root thickness, root branching and grain weight per plant. Root volume showed significant negative correlation with root thickness at phenotypic and genotypic levels $(-0.124,-0.286)$, but had positive correlation with fresh root weight $(0.340,0.917)$ and dry root weight $(0.338,0.910)$. Root volume and root thickness exhibited counteracting relationships with primary branching, secondary branching, spikelets number per panicle and spikelet fertility. Root branching was significantly correlated with grain weight per plant at genotypic level. The diffused relationships of root traits with the vegetative and reproductive traits underscore their intricate nature and require consideration in trait selection for direct and indirect increase in grain production.
\end{abstract}

(Received: 12:03:2017; Accepted: 30:03:2017)

Keywords: Root volume, root thickness, root dry weight, drought, grain yield. Correspondence: adesola.nassir@oouagoiwoye.edu.ng; adesolanassir@gmail.com

\section{Introduction}

Drought studies in rice have focussed on the improvement of root traits which would improve the ability of plants to obtain water from the soil and thereby improve vegetative and reproductive traits. A number of root traits have been identified with increased drought tolerance in rice. These include deep rooting, which is also related to thick roots and increase root diameter; and dry root weight (Ekanayake et. al., 1985; Fukai and Cooper, 1995; Price et. al., 2002; Lafitte et. al., 2006; Nassir and Adewusi, 2011). In addition, differences in total root length, including nodal and lateral roots (Wang et. al., 2009) have been reported to aid uptake of water under drought conditions. Adewusi and Nassir (2010) however observed that superior expression of root traits, which may be advantageous in improving for drought tolerance and grain yield in established varieties, are found in different genotypes. Veeresh et. al. (2011) reported deep rooting as a most accepted target trait for drought resistance in rice but also noted the existence of genetic variation for a number of other root traits important to rice response to drought. Nassir and Adewusi (2015) also observed that root traits, particularly root volume and root thickness perform differently under different conditions. It would therefore be advantageous to have a 
detailed understanding of the relationship of some of these traits with vegetative and grain yield indices. Significant correlation of root length with some rice seedling vigour indices has been reported by Redona and Mackill (1996). Adewusi and Nassir (2010) had also reported significant phenotypic correlations of root volume and weight with some other root and vegetative traits. There was, however, a large amount of variation in root trait expression due to soil and moisture differences, thus making the correlations less reliable for selection under variable soil moisture conditions.

Additionally, gene associations within rice germplasm are frequently being reconstituted as new genotypes are developed such that linkage associations, would, expectedly, also change (Nassir and Ariyo, 2006). Constant evaluation of new populations with new gene combinations and linkage associations would thereby offer opportunities for a clearer understanding of genetic control of products of recombination. This would be useful for breeding programmes for specific relationships between root traits and also for general knowledge where existing trait relationships are confirmed.

\section{Materials and methods}

Sixteen genotypes of upland rice used in this study were obtained from the Africa Rice Center at the International Institute for Tropical Agriculture (IITA), Ibadan, Nigeria. The genotypes comprise breeding lines: WAB 880-9-32-1-1-12-HB, WAB 56-50, WAB 224-8HB, WAB 189-B-B-B-HB, WAB 337-B-B-20-1129 and $W A B$ 181-18; established genotypes ITA 150, ITA 321, ITA 257, 0S6 and IRAT 170, and recent releases from $O$. sativa $\times O$. glaberimma: NERICA 1 (WAB 450-1-B-38-HB), NERICA 2 (WAB 450-11-1-P31-1-HB), NERICA 3 (WAB 450-1-B-P-28-HB), NERICA 4 (WAB 450-1-B-P-91-HB), and NERICA 5 (WAB 45011-1-P31-HB).

This study location was at the greenhouse of the College of Agricultural Sciences, Olabisi Onabanjo University, Ayetoro located in derived savannah ecology of Southwest Nigeria $\left(6.5^{\circ} \mathrm{N}, 10^{\circ} \mathrm{E}\right)$. Three weeks old seedlings of the rice genotypes were transplanted into black polythene bags filled with $5 \mathrm{~kg}$ of alluvial loam top soil obtained from the upland paddy. The polythene bags, $28 \mathrm{~cm}$ in both diameter and depth were arranged in a completely randomized designed with three replicates. All plants were watered to field capacity up to two weeks after transplanting. Preliminary study at the location had shown that rice plants require an average of 1.6 litres per plant per week at the maximum tillering, 2.4 litres per plant per week at panicle initiation and 3.2 litres per plant per week during grain filling. For this study, plants received $100 \%, 75 \%$ and $50 \%$ of moisture needs at each of maximum tillering, panicle initiation and grain filling or ripening stage growth respectively. This was applied as twice weekly and weekly applications regime. In totality, there were six soil moisture mediated environments made up of a factorial arrangement of three growth stages and two water regimes.

\section{Data collection and analysis}

Data on tiller number, leaf number, plant height, were obtained on plant basis (Anon, 1988). At maturity, panicles were harvested and used to determine panicle and grain characters: panicle number, panicle length $(\mathrm{cm})$, primary and secondary branching, grain weight per plant $(\mathrm{g})$, grain weight per panicle $(\mathrm{g})$, hundred grain weight (g), spikelet number per panicle and spikelets fertility. After harvesting, the remaining plant parts were recovered by carefully washing off the soil from the roots. The shoot and the roots were separated and used to obtain fresh root weight, fresh shoot weight and root volume.

Root characters were measured as described below by IRTP/IRRI (1976) and as used by Ekanayake et al. (1985) following the range; Root thickness: $1=$ all roots thicker than $2 \mathrm{~mm}$ and $9=$ all roots thinner than 1 $\mathrm{mm}$; Root branching: 1 = little branching and 4 = extensive branching. Root volume was measured as volume of displaced water when soil free root was inserted in distilled water. Analysis of variance was done with the GENSTAT Statistical package, Version 12, after which mean squares were partitioned to obtain phenotypic, genotypic and environmental variances as described by Breese (1969). Phenotypic and genotypic variances and coefficient of variability, broad sense heritability and correlations were obtained following the method of Singh (1991). Percent Genetic Advance (\%GA) was obtained as percent value of the proportion of GA to the mean for each trait (Singh, 2001). 


\section{Results and Discussion}

The mean squares, character means, phenotypic and genotypic coefficient of variability, heritability and genetic advance for upland rice genotypes under different moisture conditions are presented in Table 1 . The mean squares for the characters vary significantly ( $p$ $<0.01$ ) implying the existence of appreciable variation that could be further exploited for improved trait expression. The phenotypic coefficient of variation (PCV) estimates were much higher than the genotypic coefficient of variation (GCV) and gives indication of some amount environmental effect harboured by the former. The variability in the cultivation conditions usually contributes to the differences between PCV and GCV. For root traits, GCV ranged from $19.0 \%$ for dry root weight to $64.6 \%$ for root branching while vegetative traits recorded relatively lower GCV which ranged from $3.8 \%$ for plant height to $20.0 \%$ for dry shoot weight.

Differences in GCV is a mainly a function of the additive and epistatic effects and their interactions. Although this is normally the case (Singh and Choudhary, 1996, Nassir and Ariyo, 2006, Mohankumar et. al., 2011), the basis of the environmental influence must be disaggregated at the level of plant traits and their relationships. Heritability estimates were generally low the highest being 36.6 for root thickness. Among vegetative traits, tiller number recorded the highest heritability estimate of $15.1 \%$. The genetic gain values for vegetative traits were also concomitantly lower compared to root traits. From this study, a relatively higher genetic improvement over time is to be expected for root traits compared to vegetative traits in rice. This, it would seem, would be better achieved when the appropriate screening environment is used. The low $\mathrm{H}$ and GA in this study would ordinarily imply poor opportunity for a meaningful gain in selection, however, with a \%GA value of 60.7 for root branching, 35.0 for root thickness and 26.4 for grain weight per plant, some reasonable amount of selection would expectedly translate to improvement in rooting and grain production in a short time.

The PCV and GCV for reproductive traits were also generally low except for grain weight per plant which had the highest PCV and GCV values of 120.8 and 44.1 respectively. Moderate heritability was obtained for 100 -grain weight (48.7\%), days to flowering (47.8\%) and primary branching (45.9\%). The low GCV and heritability resulted in low genetic advance, with the consequence being little progress in selection for trait improvement. The genotypes used in this study are improved selections hence grain yield traits would have benefitted from intense selection over the years. Increase in grain yield is however possible given the moderate GCV, though this would require a number of cycles of direct selection for grain production and indirect selection of root and vegetative traits.

Table 2 shows the phenotypic and genotypic correlations among some root characters of rice. Root volume was inversely correlated with root thickness at phenotypic ($0.124 ; \quad p<0.05)$ and genotypic $(-0.286$; $\mathrm{p}<0.01)$ levels. Root volume also exhibited significant $(p<0.01)$ and positive phenotypic and genotypic relationship with fresh root weight $(0.340,0.917)$ and dry root weight $(0.338,0.910)$ respectively. Root volume would thereby increase with increasing selection against root thickness and vice versa. By implication, however, selection for root thickness or related traits in the development of the varieties used has possibly failed to take cognizance of the need for increase in root volume, to scout for more moisture and hence tolerate drought. There is no evidence in literature to suggest pleiotropic control of contrasting expression of root thickness and volume, however. Consequently, it should be possible to focus on development of genotypes with a joint expression of increasing values of these traits for greater drought tolerance.

Root thickness was also negatively correlated $(p<0.01)$ with root branching ($0.220,-0.431)$ at phenotypic and genotypic levels respectively. The trait also showed negative genotypic correlation with fresh root weight $(-0.228)$. Genotypes with thick roots are, therefore, expected to branch less and to have lower root volume. Contrasting interaction of root thickness and volume with cultivation environment has been reported by Nassir and Adewusi (2015). This counteracting expression must be considered for directional selections in breeding for higher expression of root volume, thickness and branching.

The phenotypic and genotypic correlations of root characters of upland rice with some plant vegetative measurements are summarized in Table 3 . Root volume 
expressed significant positive phenotypic and genotypic correlations with leaf number, fresh shoot and dry shoot weight. Its relationship at genotypic level was also positive with tiller number (0.137) but inverse with plant height $(-0.344)$. Root thickness was significantly positively related with all vegetative traits at the genotypic level, with the exception of plant height. Root branching instructively had significant negative genotypic correlation $(p<0.01)$ with plant height $(-0.594)$, fresh shoot weight $(-0.160)$ and dry shoot weight (0.159). Both fresh root and dry root weight also followed the same pattern with root volume in their relationship with the vegetative traits. The possibility of joint directional selection of most of the root and vegetative character should be beneficial, especially as there have been reports of positive relationship of a number of vegetative traits with grain yield (Kato and Takeda, 1996, Nassir and Ariyo, 2006). In consideration of the compensatory relationship of plant height with the root characters, this has to be given special attention since upland rice benefits from tall stature due to better competitiveness with weeds.

Table 4 presents the phenotypic and genotypic and genotypic correlations of root characters of upland rice with some grain yield characters. Root volume exhibited positive significant genotypic correlations with panicle number (0.141), primary branching (0.382), secondary branching (0.342), spikelets number per panicle $(0.182)$ but negative with spikelet fertility (-0.395). At phenotypic and genotypic levels, days to flowering was positively correlated with root thickness $(0.352,0.472)$ but was negatively correlated with root branching $(-0.171,-0.266)$. Root thickness also had significant negative genotypic correlation with panicle length ($0.125)$, secondary branching $(-0.490)$, and spikelet number per panicle $(-0.140)$. Its genotypic correlations with grain weight per panicle, 100-grain weight and spikelets fertility were however positive and significant. Spikelet fertility was also positively related to root branching and fresh root weight but showed negative correlation with dry root weight. Grain weight per plant, which cumulatively would translate to yield over an area, was not correlated to with most of the root traits, the exception being root branching at genotypic level (0.152). Primary and secondary branching of panicles showed similar positive and significant relationship with the root traits except with root thickness, where the relationship with secondary branching was significant but negative at both phenotypic ($0.154)$ and genotypic $(-0.490)$ levels.

The significant positive correlation of most of the yield related traits to root characters indicate some useful synergy in selection for drought tolerance and grain yield increases. However, the counteracting expressions of root thickness with panicle length, secondary branching and spikelets number per panicle; root branching with days to flowering and panicle length and of spikelet fertility with root volume and root dry weight would require consistent attention for a meaningful gain in the twin effort of improving drought tolerance and grain yield. Increase in number of spikelets per panicle, which is usually a consequence of higher primary and secondary branching, is often associated with lower percentage of filled grains (Kato and Takeda, 1996; Nassir and Akinsanya, 2003; Nassir and Ariyo, 2006). Nonetheless, genotypes with higher number of spikelets usually produce more filled grains per unit area of land (yield) especially when coupled to higher vegetativeness due to higher tiller number (Wu et. al., 1998). The lack of correlation of grain weight per plant with most root traits points to the need to breed for beneficial root traits with the grain production. Direct selection for joint expression of these traits would hopefully be beneficial.

\section{Conclusion}

There is the need to further institute crosses involving donor genotypes and NERICA varieties which, ordinarily, are expected to harbour appreciable genes for drought adaptive traits. This should target increase in both root volume and thickness though with the added efforts towards ensuring simultaneous increase in tolerance to limiting soil water condition and improvement of grain yield. In addition, adequate attention should also be given to the indirect influence on grain yield through yield components like primary and secondary branching. 
Nasir et. al. /Nig. J. Biotech. 32 (2017) 61 - 68

Table 1. Mean Squares (MS) Phenotypic and Genotypic Coefficient of variability (PCV, GCV)) Broad Sense Heritability (HB) and Genetic Advance (GA) of root, vegetative and yield traits of upland rice under imposed moisture stress

\begin{tabular}{|c|c|c|c|c|c|c|c|c|c|c|c|}
\hline Character & Mean & $\begin{array}{l}\text { Mean } \\
\text { Squares } \\
\text { (MS) }\end{array}$ & (PCV, GCV) & (HB) & $\begin{array}{l}\text { Genetic } \\
\text { Advance } \\
(\mathrm{GA})\end{array}$ & Character & Mean & $\begin{array}{l}\text { Mean } \\
\text { Squares } \\
(\mathrm{MS})\end{array}$ & $(\mathrm{PCV}, \mathrm{GCV})$ & (HB) & $\begin{array}{l}\text { Genetic } \\
\text { Advance } \\
(\mathrm{GA})\end{array}$ \\
\hline Root traits & & & & & & Reproductive/vield $t$ & aits & & & & \\
\hline $\begin{array}{l}\text { Root volume } \\
(\mathrm{RV})\left(\mathrm{cm}^{3}\right)\end{array}$ & 5.71 & $29.58^{* *}$ & $39.4,21.7$ & 15.8 & 12.8 & $\begin{array}{l}\text { Days to flowering } \\
\text { (DF) }\end{array}$ & 84.14 & $813.24 * *$ & $8.2,8.0$ & 47.8 & 8.1 \\
\hline $\begin{array}{l}\text { Root thickness } \\
\text { (RT) (s) }\end{array}$ & 7.74 & $148.44^{* *}$ & $46.5,35.6$ & 36.6 & 35.0 & $\begin{array}{l}\text { Panicle number } \\
\text { (PN) }\end{array}$ & 6.41 & $22.76^{* *}$ & $34.5,17.0$ & 12.9 & 9.2 \\
\hline $\begin{array}{l}\text { Root branching } \\
\text { (RB) (s) }\end{array}$ & 1.50 & $17.81^{* *}$ & $96.7,64.6$ & 30.5 & 60.7 & $\begin{array}{l}\text { Panicle length } \\
(\mathrm{PL})(\mathrm{cm})\end{array}$ & 25.83 & $21.28^{* *}$ & $8.3,4.2$ & 20.1 & 3.4 \\
\hline $\begin{array}{l}\text { Fresh root weight } \\
\text { (FRW) (g) }\end{array}$ & 20.02 & $293.46 * *$ & $38.1,19.5$ & 13.7 & 10.7 & $\begin{array}{l}\text { Primary branching } \\
\text { (PB) (No) }\end{array}$ & 10.03 & $10.91 * *$ & $8.3,7.8$ & 45.9 & 7.9 \\
\hline $\begin{array}{l}\text { Dry root weight } \\
\text { (DRW) (g) }\end{array}$ & 7.87 & $42.72 * *$ & $37.0,19.0$ & 13.7 & 10.4 & $\begin{array}{l}\text { Secondary } \\
\text { branching (SB) (s) }\end{array}$ & 1.07 & $1.01 * *$ & $51.6,21.8$ & 12.5 & 13.1 \\
\hline Vegetative traits & & & & & & $\begin{array}{l}\text { Grain weight per } \\
\text { panicle (GWPN) (g) }\end{array}$ & 1.71 & $0.91 * *$ & $26.1,12.7$ & 12.4 & 6.4 \\
\hline $\begin{array}{l}\text { Tiller number } \\
\text { (TN) }\end{array}$ & 11.17 & $42.8^{* *}$ & $28.5,13.9$ & 15.1 & 8.9 & $\begin{array}{l}\text { Grain weight per } \\
\text { plant (GWPT) (g) }\end{array}$ & 12.45 & $581.15^{* *}$ & $120.8,44.1$ & 10.6 & 26.4 \\
\hline $\begin{array}{l}\text { Leaf number } \\
\text { (LN) }\end{array}$ & 39.33 & $442.12 * *$ & $23.7,12.2$ & 14.3 & 7.0 & $\begin{array}{l}\text { 100-grain weight } \\
(100 \mathrm{GW})(\mathrm{g})\end{array}$ & 3.16 & $2.57^{* *}$ & $12.2,11.9$ & 48.7 & 12.3 \\
\hline $\begin{array}{l}\text { Plant height } \\
\text { (PH) }(\mathrm{cm})\end{array}$ & 110.11 & $358.12 * *$ & $13.8,3.8$ & 3.9 & 1.1 & $\begin{array}{l}\text { Spikelet number } \\
\text { per panicle (SNP) }\end{array}$ & 59.25 & $518.44^{* *}$ & $22.7,8.7$ & 7.6 & 3.5 \\
\hline $\begin{array}{l}\text { Fresh shoot weight } \\
\text { (FSW) (g) }\end{array}$ & 92.78 & $4833.30 * *$ & $45.7,16.9$ & 7.1 & 6.7 & $\begin{array}{l}\text { Spikelet fertility } \\
\text { (SF) (s) }\end{array}$ & 86.29 & $89.33 * *$ & $5.9,2.5$ & 14.0 & 1.7 \\
\hline $\begin{array}{l}\text { Dry shoot weight } \\
\text { (DSW) (g) }\end{array}$ & 27.14 & $574.98 * *$ & $45.5,20.0$ & 10.1 & 9.4 & & & & & & \\
\hline
\end{tabular}


Table 2: Phenotypic (P) and genotypic (G) correlations among root characters of upland rice under imposed moisture stress

\begin{tabular}{|c|c|c|c|c|c|c|}
\hline Character & & $\begin{array}{l}\text { Root } \\
\text { Volume } \\
\text { (cm3) }\end{array}$ & $\begin{array}{l}\text { Root } \\
\text { Thickness } \\
\text { (s) }\end{array}$ & $\begin{array}{l}\text { Root } \\
\text { Branching } \\
\text { (s) }\end{array}$ & $\begin{array}{l}\text { Fresh Root } \\
\text { Weight }(\mathrm{g})\end{array}$ & $\begin{array}{l}\text { Dry Root } \\
\text { Weight }(\mathrm{g})\end{array}$ \\
\hline Root & $P$ & & $-0.124^{*}$ & -0.016 & $0.340 * *$ & $0.338 * *$ \\
\hline Volume & G & & $-0.286 * *$ & -0.078 & $0.917^{* *}$ & $0.910 * *$ \\
\hline Root & $P$ & & & $-0.220 * *$ & -0.116 & -0.087 \\
\hline Thickness & G & & & $-0.431 * *$ & $-0.228 * *$ & -0.115 \\
\hline Root & $P$ & & & & 0.011 & -0.012 \\
\hline Branching & G & & & & -0.012 & -0.078 \\
\hline Fresh Root & P & & & & & $0.319 * *$ \\
\hline Weight & G & & & & & $0.894 * *$ \\
\hline
\end{tabular}

$\mathrm{s}=$ score ${ }^{*},{ }^{* *}=$ significant at $\mathrm{P}<0.05$ and 0.01 respectively.

Table 3: Phenotypic (P) and genotypic (G) correlations of root characters of upland rice with some vegetative characters under imposed moisture stress

\begin{tabular}{|c|c|c|c|c|c|c|}
\hline Character & & $\begin{array}{l}\text { Root Volume } \\
\text { (cm3) }\end{array}$ & $\begin{array}{l}\text { Root Thickness } \\
\text { (s) }\end{array}$ & $\begin{array}{l}\text { Root } \\
\text { Branching (s) }\end{array}$ & $\begin{array}{l}\text { Fresh Root } \\
\text { Weight }(\mathrm{g})\end{array}$ & $\begin{array}{l}\text { Dry Root } \\
\text { Weight (g) }\end{array}$ \\
\hline Tiller & $P$ & 0.096 & 0.130 & 0.037 & 0.091 & 0.093 \\
\hline Number & G & $0.137^{*}$ & $0.355 * *$ & 0.080 & $0.124 *$ & $0.131 *$ \\
\hline Leaf & $\mathrm{P}$ & $0.141^{*}$ & 0.109 & -0.025 & $0.129 *$ & $0.134 *$ \\
\hline number & G & $0.261^{* *}$ & $0.275^{* *}$ & -0.101 & $0.230 * *$ & $0.248 * *$ \\
\hline Plant height & $\mathrm{P}$ & 0.023 & -0.007 & -0.098 & 0.015 & 0.016 \\
\hline$(\mathrm{cm})$ & G & $-0.344 * *$ & -0.003 & $-0.594 * *$ & $-0.429 * *$ & $-0.423 * *$ \\
\hline Fresh Shoot & $\mathrm{P}$ & $0.171^{* *}$ & 0.042 & -0.030 & $0.164 * *$ & $0.171^{*}$ \\
\hline Weight (g) & G & $0.465 * *$ & $0.150^{*}$ & $-0.160 * *$ & $0.452 * *$ & $0.493 * *$ \\
\hline Dry Shoot & $P$ & $0.338 * *$ & 0.051 & -0.039 & $0.187 * *$ & $0.197 * *$ \\
\hline Weight (g) & G & $0.505^{* *}$ & $0.150 *$ & $-0.159 * *$ & $0.496 * *$ & $0.540 * *$ \\
\hline
\end{tabular}


Table 4: Phenotypic (P) and genotypic (G) correlations of root characters of upland rice with some vegetative characters under imposed moisture stress

\begin{tabular}{|c|c|c|c|c|c|c|}
\hline Character & & $\begin{array}{l}\text { Root Volume } \\
(\mathrm{cm} 3)\end{array}$ & $\begin{array}{c}\text { Root } \\
\text { Thickness (s) }\end{array}$ & $\begin{array}{l}\text { Root } \\
\text { Branching (s) }\end{array}$ & $\begin{array}{l}\text { Fresh Root } \\
\text { Weight }(\mathrm{g})\end{array}$ & $\begin{array}{l}\text { Dry Root } \\
\text { Weight }(\mathrm{g})\end{array}$ \\
\hline Days to flowering & $\begin{array}{l}\mathrm{P} \\
\mathrm{G}\end{array}$ & $\begin{array}{l}0.056 \\
0.076\end{array}$ & $\begin{array}{l}0.352^{* *} \\
0.472 * *\end{array}$ & $\begin{array}{l}-0.171 * * \\
-0.266 * *\end{array}$ & $\begin{array}{l}0.065 \\
0.107\end{array}$ & $\begin{array}{l}0.065 \\
0.102\end{array}$ \\
\hline Panicle number & $\begin{array}{l}P \\
G\end{array}$ & $\begin{array}{l}0.094 \\
0.141^{*}\end{array}$ & $\begin{array}{l}0.021 \\
0.049\end{array}$ & $\begin{array}{l}0.046 \\
0.121^{*}\end{array}$ & $\begin{array}{l}0.082 \\
0.094\end{array}$ & $\begin{array}{l}0.080 \\
0.084\end{array}$ \\
\hline $\begin{array}{l}\text { Panicle length } \\
(\mathrm{cm})\end{array}$ & $\begin{array}{l}P \\
G\end{array}$ & $\begin{array}{l}0.015 \\
0.040\end{array}$ & $\begin{array}{l}-0.045 \\
-0.125^{*}\end{array}$ & $\begin{array}{l}-0.067 \\
-0.204 * *\end{array}$ & $\begin{array}{l}0.009 \\
0.017\end{array}$ & $\begin{array}{l}0.024 \\
0.077\end{array}$ \\
\hline $\begin{array}{l}\text { Primary branching } \\
\text { (No) }\end{array}$ & $\begin{array}{l}P \\
G\end{array}$ & $\begin{array}{l}0.206 * * \\
0.382 * *\end{array}$ & $\begin{array}{l}-0.033 \\
-0.044\end{array}$ & $\begin{array}{l}0.106 \\
0.170 * *\end{array}$ & $\begin{array}{l}0.188^{* *} \\
0.372 * *\end{array}$ & $\begin{array}{l}0.171^{* *} \\
0.337 * *\end{array}$ \\
\hline Secondary Branching & $\begin{array}{l}P \\
G\end{array}$ & $\begin{array}{l}0.113 \\
0.342 * *\end{array}$ & $\begin{array}{l}-0.154 * \\
-0.490 * *\end{array}$ & $\begin{array}{l}0.090 \\
0.308^{* *}\end{array}$ & $\begin{array}{l}0.100 \\
0.305^{* *}\end{array}$ & $\begin{array}{l}0.088 \\
0.250 * *\end{array}$ \\
\hline $\begin{array}{l}\text { Grain Weight per } \\
\text { panicle }(\mathrm{g})\end{array}$ & $\begin{array}{l}P \\
G\end{array}$ & $\begin{array}{l}0.075 \\
0.044\end{array}$ & $\begin{array}{l}0.055 \\
0.133 *\end{array}$ & $\begin{array}{l}0.006 \\
-0.006\end{array}$ & $\begin{array}{l}0.063 \\
-0.018\end{array}$ & $\begin{array}{l}0.063 \\
-0.016\end{array}$ \\
\hline $\begin{array}{l}\text { Grain Weight per } \\
\text { plant }(\mathrm{g})\end{array}$ & $\begin{array}{l}P \\
G\end{array}$ & $\begin{array}{l}0.028 \\
-0.001\end{array}$ & $\begin{array}{l}0.024 \\
0.110\end{array}$ & $\begin{array}{l}0.044 \\
0.152^{*}\end{array}$ & $\begin{array}{l}0.022 \\
-0.039\end{array}$ & $\begin{array}{l}0.015 \\
-0.073\end{array}$ \\
\hline $\begin{array}{l}\text { 100-grain Weight } \\
\text { (g) }\end{array}$ & $\begin{array}{l}P \\
G\end{array}$ & $\begin{array}{l}-0.042 \\
-0.085\end{array}$ & $\begin{array}{l}0.217 * * \\
0.292^{* *}\end{array}$ & $\begin{array}{l}-0.037 \\
-0.056\end{array}$ & $\begin{array}{l}-0.049 \\
-0.106\end{array}$ & $\begin{array}{l}-0.027 \\
-0.062\end{array}$ \\
\hline $\begin{array}{l}\text { Spikelet Number per } \\
\text { Panicle }\end{array}$ & $\begin{array}{l}P \\
G\end{array}$ & $\begin{array}{l}0.106 \\
0.182 * *\end{array}$ & $\begin{array}{l}-0.039 \\
-0.140 *\end{array}$ & $\begin{array}{l}0.021 \\
0.051\end{array}$ & $\begin{array}{l}0.096 \\
0.126^{*}\end{array}$ & $\begin{array}{l}0.084 \\
0.070\end{array}$ \\
\hline Spikelet Fertility (s) & $\begin{array}{l}P \\
G\end{array}$ & $\begin{array}{l}-0.012 \\
-0.395^{* *}\end{array}$ & $\begin{array}{l}0.035 \\
0.378^{* *}\end{array}$ & $\begin{array}{l}0.035 \\
0.127 *\end{array}$ & $\begin{array}{l}0.086 \\
0.338^{* *}\end{array}$ & $\begin{array}{l}-0.054 \\
-0.383 * *\end{array}$ \\
\hline
\end{tabular}

$\mathrm{s}=$ score $^{*},{ }^{* *}=$ significant at $\mathrm{P}<0.05$ and 0.01 respectively.

\section{REFERENCES}

Adewusi, K. M. and A. L. Nassir (2010). Assessment of field-planted upland rice genotypes for drought adaptive and reproductive traits and in a derived savannah ecology. J. of Plant Breed. and Crop Sci. 3(11) 283-292.

Anonymous, (1988). Standard Evaluation System for Rice. $3^{\text {rd }}$ Ed., IRRI, Philippines, pp. 54.

Breese, E.L. (1969). The measurement and significant of genotype- environment interactions in rice. Heredity. 24: 27-44.

Ekanayake I. J., Garvity D. P., Masajo T. M., O'Toole J. C. (1985). A root pulling resistance of rice. Euphytica. 34 (3): 905 - 913.
Fukai S., and Cooper M. (1995). Development of drought - resistance cultivars using physiomorphological traits in rice. Field Crops Res. 40: 67- 86.

IRTP/IRRI (1988). Standard evaluation system for rice. International Rice Testing programme/International Rice Research Institute 3rd Ed. Philippine, p. 54.

Kato, T. (1996). Heritability and genetic correlation for component characters of yield sink capacity of rice. Int. Rice Res. Notes 21 (1): 15. 
Kato T and Takeda K. (1996). Associations among characters related to yield sink capacity in spaceplanted rice. Crop. Sci. 36: 1135-1139.

Lafitte H. R., Yongsheng G., Yan S., Li, Z-K (2006). Whole plant responses, key processes, and adaptation to drought stress: the case of rice. J. of Experim. Bot., 58 (2): 169-175.

Mohankumar, M. V., Sheshshayee, M. S., Rajama, M. P., and Udayakumar, M. (2011). Correlation and path analysis of drought tolerance traits on grain yield in rice germplasm accessions. ARPN J. of Biol. Sc. 6 (7): $70-77$.

Nassir A. L. and Adewusi K. M. (2015). Genotype $x$ Environment analysis of root traits of upland rice (Oryza sativa) in a drought prone tropical rainfed ecology. Tropical Agriculture, Trinidad 92 (1): 16 $-26$.

Nassir A. L. and Akinsanya J. (2003). Plant character correlations heritability and path analysis of yield sink capacity of rice (Oryza sativa). J. Sust. Agric. \& Env. 5(1): 84-91.

Nassir, A. L. and Adewusi, K. M. (2011). Drought response of some tropical rice genotypes: Rooting, vegetative traits and grain production. African J. of Plant Sci. 5(12): 710-717.

Nassir, A. L., Ariyo, O. J. (2006). Plant character correlations and path analysis of grain yield in rice (Oryza sativa). J. of Genet. and Breed. 60: 161172.

Price, A. H., Steele, K. A., Moore, B. J., Jones, R. G. W. (2002). Upland rice grown in soil-filled chambers and exposed to contrasting water deficit regimes II. Mapping quantitative trait loci for root morphology and distribution. Field Crops Res. 76: 25-43.

Redona, E. D. and Mackill, D. J. (1996). Genetic variation for seedling vigor traits in rice. Crop Sci. 36: 285-290.

Singh, B. D. (2001). Plant Breeding: Principles and Methods. $9^{\text {th }}$ Ed. New Delhi. Kalyani Publishers. Pp. 167-168.

Singh, M. (1991). Genotypic and phenotypic correlations in plant traits. Syria. Int. Cent. for Agric. Res. in the Dry Areas. pp. 277

Singh, S. and Choudhary, B. S., 1996. Variability, heritability and genetic advance in cultivars of rice Oryza sativa L. Crop Res. 12 (2): 165-167.

Veeresh, R. P., Gowdaa, B., Amelia, H., Akira, Y., Shashidharb, H. E., Rachid, S. (2011). Root biology and genetic improvement for drought avoidance in rice. Field Crops Research. 30: $301-$ 313.

Wang H., Siopongcob, J., Wade L. J., Yamauchi A. (2009). Fractal analysis on root systems of rice plants in response to drought stress. Env. and Exp. Bot. 65: 338-344.

Wu, G., Wilson L.T. and McClung A. (1998). Contribution of rice tillers to dry matter accumulation and yield. Agron. J. 90: 317-323. 